\title{
Pharmacogenetic profiling and cetuximab outcome in patients with advanced colorectal cancer
}

Laetitia Dahan $^{1,2^{*}{ }^{\dagger}}$, Emmanuelle Norguet $^{1+}{ }^{\dagger}$, Marie-Christine Etienne-Grimaldi ${ }^{2}$, Jean-Louis Formento ${ }^{2}$, Mohamed Gasmi ${ }^{3}$ Isabelle Nanni ${ }^{3}$, Jean Gaudart', Stéphane Garcia ${ }^{3}$, L'Houcine Ouafik $^{3}$, Jean-François Seitz ${ }^{1 \dagger}$ and Gérard Milano ${ }^{2+}$

\begin{abstract}
Background: We analyzed the influence of 8 germinal polymorphisms of candidate genes potentially related to EGFR signalling (EGFR, EGF, CCND1) or antibody-directed cell cytotoxicity (FCGR2A and FCGR3A) on outcome of colorectal cancer (CRC) patients receiving cetuximab-based therapy.
\end{abstract}

Methods: Fifty-eight advanced CRC patients treated with cetuximab-irinotecan salvage therapy between 2001 and 2007 were analyzed (mean age 60; 50 PS 0-1). The following polymorphisms were analyzed on blood DNA: EGFR (CA repeats in intron 1,-216 G > T, -191C > A, R497K), EGF (A61G), CCND1 (A870G), FCGR2A (R131H), FCGR3A (F158V). Statistical analyses were conducted on the total population and on patients with wt KRas tumors. All SNPS were considered as ternary variables (wt/wt vs wt/mut vs mut/mut), with the exception of -191C > A EGFR polymorphism (AA patient merged with CA patients).

Results: Analysis of skin toxicity as a function of EGFR intron 1 polymorphism showed a tendency for higher toxicity in patients with a low number of CA-repeats $(p=0.058)$. CCND1 A870G polymorphism was significantly related to clinical response, both in the entire population and in KRas wt patients, with the G allele being associated with a lack of response. In wt KRas patients, time to progression (TTP) was significantly related to EGFR -191C > A polymorphism with a longer TTP in CC patients as compared to others, and to CCND1 A870G polymorphism with the $\mathrm{G}$ allele being associated with a shorter TTP; a multivariate analysis including these two polymorphisms only retained CCND1 polymorphism. Overall survival was significantly related to CCND1 polymorphism with a shorter survival in patients bearing the G allele, and to FCGR3A F158V polymorphism with a shorter survival in W patients (in the entire population and in KRas wt patients). FCGR3A F158V and CCND1 A870G polymorphisms were significant independent predictors of overall survival.

Conclusions: Present original data obtained in wt KRas patients corresponding to the current cetuximab-treated population clearly suggest that CCND1 A870G polymorphism may be used as an additional marker for predicting cetuximab efficacy, TTP and overall survival. In addition, FCGR3A F158V polymorphism was a significant independent predictor of overall survival.

Keywords: EGFR inhibitors, cetuximab, clinical outcome, colorectal cancer, polymorphisms

\footnotetext{
* Correspondence: laetitia.dahan@mail.ap-hm.fr

+ Contributed equally

'Assistance Publique-Hôpitaux de Marseille, Hôpital Timone, Université de la

Méditerranée, Marseille, France

Full list of author information is available at the end of the article
} 


\section{Introduction}

Despite the introduction of new treatments, the 5-year survival rate for metastatic colorectal cancer (mCRC) remains below 10\% [1]. Cetuximab, an IgG1 monoclonal antibody (MoAb) targeting epidermal growth factor receptor (EGFR), has proven to be effective in providing clinical benefit in approximately $10 \%$ to $20 \%$ of patients [2-4]. EGFR is a transmembrane tyrosine kinase receptor that, following ligand binding, triggers two main signaling pathways: the RAS-RAF-MAPK pathway which is involved in cell proliferation, and the PI3K-PTEN-AKT pathway which controls cell survival and motility [5].

While the presence of a KRAS mutation permits identification of tumors that are insensitive to these treatments, only less than half of patients with a KRAS wild type (wt) tumor will benefit from treatments, suggesting a role for additional mechanisms of resistance [6-10]. It thus appears necessary to better define the subpopulation of patients who truly benefit from cetuximab. One approach to resolving this question may be the application of pharmacogenetics, as recently reviewed by Coate and co-workers [11]. Yet, gene polymorphisms may affect pharmacodynamics of anti-EGFR therapies such as cetuximab, by introducing inter-patient variability at the level of the EGFR target itself, the EGF ligand, as well as in the immunological mechanism called antibody-dependent cellular cytotoxicity (ADCC).

Four functional EGFR variants have been associated with EGFR regulation [12-14]: a (CA)n repeat polymorphism in EGFR intron 1, a G > A single nucleotide polymorphism (SNP) at codon 497, and two SNPs -216 $\mathrm{G}>\mathrm{T}$ and $-191 \mathrm{C}>\mathrm{A}$ located in the promoter region. Modulation of the EGFR ligand EGF and of the downstream EGFR signaling, including the cyclin-D1 gene $(C C N D 1)$, may also play a role in modulating cetuximab activity. Functional variants have been described in the EGF 5'-untranslated region (EGF $61 \mathrm{G}>\mathrm{A}$ ) $[15,16]$, and in the exon 4 of the CCND1 gene $(870 \mathrm{~A}>\mathrm{G})[17,18]$. The ADCC, mediated through Fc receptors (Fc $\gamma \mathrm{R})$ carried by immune cells such as macrophages and natural killer cells, plays an important role in the antitumor effect of IgG1 antibodies, such as cetuximab $[19,20]$. The effectiveness of ADCC may depend on the degree of activation of $\mathrm{F} c \gamma \mathrm{R}$ and constitutional polymorphisms have been demonstrated on genes encoding for these receptors: a histidine $(\mathrm{H}) / \operatorname{arginine}(\mathrm{R})$ polymorphism at position 131 for $F C G R 2 A$ and a valine $(\mathrm{V}) /$ phenylalanine (F) polymorphism at position 158 for FCGR3A [21].

In the present study, we investigated possible associations between these genetic variants and clinical outcomes of advanced CRC patients treated with cetuximab. Clinical end points were skin toxicity, clinical response, time to progression (TTP) and overall survival (OS).

\section{Materials and methods \\ Patients}

Fifty-eight patients with advanced colorectal carcinoma were included in this retrospective pharmacogenetic study. All were treated between December 2001 and November 2007. Forty-four patients were treated at the Hôpital La Timone and 14 at the Hôpital Nord (Marseille). The study was carried out with ethics committee approval and patients signed a specific informed consent for pharmacogenetic analyses. Patient characteristics are shown in Table 1. Formalin-fixed, paraffin-embedded tumor material was collected retrospectively for 50 patients. After histological control (HES) and macrodissection to select tumor areas containing at least 50\%

\section{Table 1 Patient characteristics $(\mathrm{N}=58)$}

\begin{tabular}{|c|c|c|}
\hline \multirow[t]{2}{*}{ Age (years) } & Mean & 60.2 \\
\hline & Range & $32-83$ \\
\hline \multirow[t]{2}{*}{ Gender } & Men & 36 \\
\hline & Women & 22 \\
\hline \multirow[t]{4}{*}{ PS } & 0 & 28 \\
\hline & 1 & 22 \\
\hline & 2 & 6 \\
\hline & 3 & 2 \\
\hline \multirow[t]{2}{*}{ Adjuvant chemotherapy } & No & 41 \\
\hline & Yes & 17 \\
\hline \multirow[t]{4}{*}{ Primary tumor localization } & Right colon & 6 \\
\hline & Left colon & 30 \\
\hline & Rectum & 21 \\
\hline & Unknown & 1 \\
\hline \multirow[t]{4}{*}{ Metastasis characteristics } & Single & 23 \\
\hline & Multiple & 35 \\
\hline & Synchronous & 36 \\
\hline & Metachronous & 22 \\
\hline \multirow[t]{3}{*}{ KRAS mutation status } & Non-mutated & 34 \\
\hline & $\begin{array}{l}\text { Mutated at } \\
\text { codon } 12 \text { or } 13\end{array}$ & 16 \\
\hline & Unknown & 8 \\
\hline \multirow{2}{*}{$\begin{array}{l}\text { Previous administration of } \\
\text { bevacizumab for metastatic disease }\end{array}$} & No & 45 \\
\hline & Yes & 13 \\
\hline \multirow[t]{4}{*}{ Line of cetuximab treatment } & First & 1 \\
\hline & Second & 8 \\
\hline & Third & 32 \\
\hline & $\geq 4^{\text {th }}$ & 17 \\
\hline \multirow{4}{*}{$\begin{array}{l}\text { Chemotherapy associated with } \\
\text { cetuximab }\end{array}$} & None & 2 \\
\hline & Irinotecan & 41 \\
\hline & FOLFIRI & 14 \\
\hline & FOLFOX & 1 \\
\hline \multirow[t]{3}{*}{ Number of cetuximab cycles } & Mean & 7.6 \\
\hline & Median & 6.0 \\
\hline & Range & $1-29$ \\
\hline
\end{tabular}


tumor cells, DNA was extracted, and activating mutations of KRAS gene at codon 12 and codon 13 were analyzed by direct sequencing (Big Dye Terminator cycle sequencing kit, Applied Biosystems, Foster City, CA) on a 3130 genetic analyzer (Applied Biosystems). A KRAS mutation was detected in $32 \%$ of patients (16/50). The majority of patients (55\%) received cetuximab as third-line therapy, and the associated chemotherapy was irinotecan for $71 \%$ of patients. Thirteen patients out of 58 had received previous therapy with bevacizumab for their metastatic disease. Cetuximab was administered i.v. over $2 \mathrm{hr}$ at day1-day8-day15 $\left(400 \mathrm{mg} / \mathrm{m}^{2}\right.$ starting dose, $250 \mathrm{mg} / \mathrm{m}^{2}$ for subsequent doses, 21 -day cycles). Treatment was administered until disease progression or unacceptable toxicity.

\section{Toxicity evaluation}

Toxicity evaluation focused on cetuximab-related toxicity, i.e. acneiform rash. The maximum observed toxicity grade was recorded for all patients $(\mathrm{N}=58)$, according to NCI-CTCAE v3.0.

\section{Efficacy evaluation}

Best clinical response, assessed according to modified RECIST criteria, was assessable on 56 patients (2 patients were not evaluated because of early treatment interruption due to toxicity). Time to progression (TTP) and specific survival (cancer-related death) were computed from day- 1 of cetuximab treatment. At time of analysis, 51 patients out of 56 assessable patients had progressed. Survival was recorded in 57 patients among whom 44 had died from their cancer and one had died from an independent cause. Median follow-up was 39.2 months (reverse Kaplan-Meier method).

\section{Pharmacogenetic analyses}

Germinal polymorphisms of EGFR, EGF, CCND1, FCGR2A and FCGR3A genes, potentially linked to cetuximab pharmacodynamics, were analyzed on DNA extracted from a $9 \mathrm{ml}$ blood sample (Paxgene Blood DNA kit, Prenalytics). With the exception of the EGFR intron-1 polymorphism, all other variants were investigated using a polymerase chain reaction-restriction fragment length polymorphism (PCR-RFLP) method (Table 2). Electrophoresis separation was performed on a 3\% agarose gel. The CA-repeats polymorphism in intron 1 of EGFR gene was analyzed by fluorescent genotyping on CEQ-8000 Beckman-Coulter, as previously described [22]. Due to the large number of genotypes (between 14 and 20 CA repeats), patients were split into 2 groups (patients with the sum of CA repeats $\leq 35 v s$ others). Wild-type and mutated cell lines were used as controls.

\section{Statistics}

The Exact $\mathrm{p}$ values for Hardy-Weinberg equilibrium were tested on http://innateimmunity.net/IIPGA2. All SNPs were considered as ternary categorical variables (wt/wt $v s \mathrm{wt} / \mathrm{mut} v s \mathrm{mut} / \mathrm{mut}$ ), with the exception of $-191 C$ > A EGFR polymorphism for which the only AA patient was merged with heterozygous patients. Nonparametric tests were performed for comparisons (Mann-Whitney or Kruskal-Wallis). Pearson chi-square tests were applied for categorical variables, including linkage disequilibrium analyses. A logistic model was applied for estimation of odds ratio (OR) associated with toxicity $(1=$ grade $2-3,0=$ grade $0-1)$ or response $(1=\mathrm{CR}+\mathrm{PR}, 0=\mathrm{SD}+\mathrm{PD})$. TTP and survival curves were plotted according to the Kaplan-Meier method.

Table 2 Characteristics of the PCR-RFLP methods used

\begin{tabular}{|c|c|c|c|}
\hline Gene & SNP & $\begin{array}{l}\text { Restriction } \\
\text { Enzyme }\end{array}$ & Primers \\
\hline$E G F R$ & $\begin{array}{l}497 R>K \\
r s 2227983\end{array}$ & BstNI & $\begin{array}{l}\text { 5-TGCTGTGACCCACTCTGTCT-3 } \\
\text { 5-CCAGAAGGTTGCACTTGTCC-3 }\end{array}$ \\
\hline EGFR & $\begin{array}{l}-216 \mathrm{G}>\mathrm{T} \\
\text { rs712829 }\end{array}$ & BseRl & $\begin{array}{l}\text { 5-CCACCGCCTCCGGCGGCCGCTGGCCTTG-3 } \\
\text { 5-CGGCGAGACACGCCCTTACCTाT-3 }\end{array}$ \\
\hline$E G F R$ & $\begin{array}{l}-191 C>A \\
\text { rs712830 }\end{array}$ & Sacll & $\begin{array}{l}\text { 5-CCACCGCCTCCGGCGGCCGCTGGCCTTG-3 } \\
\text { 5-CGGCGAGACACGCCCTTACCTाT-3 }\end{array}$ \\
\hline$E G F$ & $\begin{array}{c}61 A>G \\
r s 4444903\end{array}$ & Alul & $\begin{array}{l}\text { 5-TGTCACTAAAGGAAAGGAGGT-3 } \\
\text { 5-TTCACAGAGTTAACAGCCC-3 }\end{array}$ \\
\hline CCND1 & $\begin{array}{l}870 A>G \\
\text { rs603965 }\end{array}$ & ScrFl & $\begin{array}{l}\text { 5-GTGAAGTTCATTTCCAATCCGC-3 } \\
\text { 5-GGGACATCACCCTCACTTAC-3 }\end{array}$ \\
\hline FCGR2A & $\begin{array}{l}131 R>H \\
r s 1801274\end{array}$ & BstUI & $\begin{array}{l}\text { 5-GGAAAATCCCAGAAATTCTCGC-3 } \\
\text { 5-CAACAGCCTGACTACCTATTACGCGGG-3 }\end{array}$ \\
\hline \multirow[t]{2}{*}{ FCGR3A } & $\begin{array}{l}158 \mathrm{~F}>V \\
\mathrm{rs} 396991\end{array}$ & Nlalll & $\begin{array}{l}\text { First PCR: } \\
\text { 5-ATATTTACAGAATGGCACAGG-3 } \\
\text { 5-GACTTGGTACCCAGGTTGAA-3 }\end{array}$ \\
\hline & & & $\begin{array}{l}\text { Second PCR: } \\
\text { 5-ATCAGATTCGATCCTACTTCTGCAGGGGGCAT-3 } \\
\text { 5-ACGTGCTGAGCTTGAGTGATGGTGATGTTCAC-3 }\end{array}$ \\
\hline
\end{tabular}


The influence of the various tested parameters on TTP and survival was assessed by means of Log Rank test, or Cox analysis (for continuous variables or multivariate analysis). For stepwise multivariate analyses, the probabilities for entry and removal were 0.05 and 0.10 , respectively. Whatever the gene polymorphism and the clinical end-point, we firstly performed univariate analyses, and then included the significant genotypes ( $\mathrm{p} \leq$ 0.050 from univariate analyses) in a single multivariate analysis. In addition, for efficacy end-points (response, TTP and survival), we conducted additional univariate and multivariate analyses on the sub-population of KRas wt patients. The $\mathrm{p}$ value considered as statistically significant ( $\mathrm{p} \leq 0.05$, two-sided test) was not corrected for multiple testing. Statistics were performed on SPSS software (v15.0).

\section{Results}

\section{Description of gene polymorphisms}

Table 3 depicts the frequency of analyzed genotypes. Regarding intron 1 EGFR polymorphism, homozygous 16-16 CA repeats was the most frequent genotype (29.3\%), followed by heterozygous 16-20 CA repeats (22.4\%) and 16-18 CA repeats (10.3\%). All bi-allelic genotypes agreed well with those predicted by the HardyWeinberg equilibrium. No linkage disequilibrium was observed between EGFR -216 G > T, $-191 \mathrm{C}>\mathrm{A}$ and

Table 3 Distribution of gene polymorphisms

\begin{tabular}{|c|c|c|c|}
\hline Gene & Genotype & & $\mathrm{N}$ \\
\hline \multirow[t]{11}{*}{$E G F R$} & CA-repeats (intron 1) & Sum of $C A \leq 35$ & 33 \\
\hline & & Sum of CA > 35 & 23 \\
\hline & $-216 \mathrm{G}>\mathrm{T}$ & GG & 16 \\
\hline & & GT & 29 \\
\hline & & $\pi$ & 11 \\
\hline & $-191 C>A$ & CC & 45 \\
\hline & & CA & 11 \\
\hline & & AA & 1 \\
\hline & R497K & $\mathrm{RR}$ & 29 \\
\hline & & RK & 18 \\
\hline & & KK & 8 \\
\hline \multirow[t]{3}{*}{ EGF } & $61 A>G$ & $\mathrm{AA}$ & 25 \\
\hline & & $A G$ & 21 \\
\hline & & GG & 9 \\
\hline \multirow[t]{3}{*}{ CCND1 } & A870G & $\mathrm{AA}$ & 9 \\
\hline & & $A G$ & 35 \\
\hline & & GG & 12 \\
\hline \multirow[t]{3}{*}{ FCGR2A } & $\mathrm{R} 131 \mathrm{H}$ & $\mathrm{RR}$ & 20 \\
\hline & & $\mathrm{RH}$ & 29 \\
\hline & & $\mathrm{HH}$ & 7 \\
\hline \multirow[t]{3}{*}{ FCGR3A } & F158V & $\mathrm{FF}$ & 30 \\
\hline & & $\mathrm{FV}$ & 20 \\
\hline & & W & 6 \\
\hline
\end{tabular}

R497K polymorphisms, nor between FCGR2A H131R and FCGR3A V158F polymorphisms. Tumoral K-Ras mutation status was not related to polymorphisms of genes linked to the EGFR pathway (EGFR, EGF, CCND1).

\section{Impact of gene polymorphisms on toxicity}

Maximum observed cetuximab-related acneiform rash was grade 0 in 7 patients, grade 1 in 14 patients, grade 2 in 28 patients and grade 3 in 9 patients, accounting for a total of $63.8 \%$ toxicity grade $2-3$. This toxicity was not related to performance status or patient age, but was unexpectedly linked to patient gender, with a significantly greater toxicity in men as compared to women (77.8\% vs 40.9\%, $\mathrm{p}=0.005$ ).

A tendency was observed for greater cutaneous toxicity in patients bearing short CA repeats in intron 1 of EGFR gene, with $72.7 \%$ grade $2-3$ in patients with CA sum $\leq 35$ vs $47.8 \%$ in patients with CA sum > 35 (Figure $1, \mathrm{p}=0.058, \mathrm{OR}=2.91,95 \%$ CI $0.95-8.92)$. No relevant relationship was observed for the other analyzed polymorphisms.

\section{Impact of gene polymorphisms on response}

Best clinical response was CR in one patient, PR in 5 patients, stabilization in 11 patients and progression in 39 patients (i.e. $10.7 \%$ response rate, $C R+P R$ ). Even though response rate was greater in patients developing cutaneous toxicity ( $13.9 \%$ in patients with grade $2-3 \mathrm{vs}$ $5.0 \%$ in patients with grade $0-1)$, this difference did not reach statistical significance $(\mathrm{p}=0.30)$. In other respects, response rate was $15.2 \%$ in patients with non-mutated KRas tumors vs $0 \%$ in patients with KRas mutated tumors $(\mathrm{p}=0.11)$.

Regarding gene polymorphisms, CCND1 polymorphism at position A870G was significantly related to clinical response (Figure 2, AA vs AG vs GG, p = 0.016). Interestingly, an analysis restricted to patients with KRas wt tumors confirms the predictive value of CCND1 A870G polymorphism on clinical response (AA vs AG vs $\mathrm{GG}, \mathrm{p}=0.027$ ), with the presence of the $\mathrm{G}$ allele being associated with a lack of response (AA vs AG $+\mathrm{GG}, \mathrm{p}=0.007$, OR relative to $\mathrm{GG}+\mathrm{AG}$ patients was 39.0, 95\% CI 2.67-569.7). No relevant relationship was observed for the other analyzed polymorphisms.

\section{Impact of gene polymorphisms on TTP and specific survival}

Median TTP was 2.8 months. TTP was not influenced by demographic or tumor characteristics, including K-Ras mutation status, with the exception of a slight influence of primary tumor localization (shorter TTP in patients with right colon primary cancer, $\mathrm{p}=0.027$ ). Univariate analyses showed that only $-191 \mathrm{C}>\mathrm{A} E G F R$ 


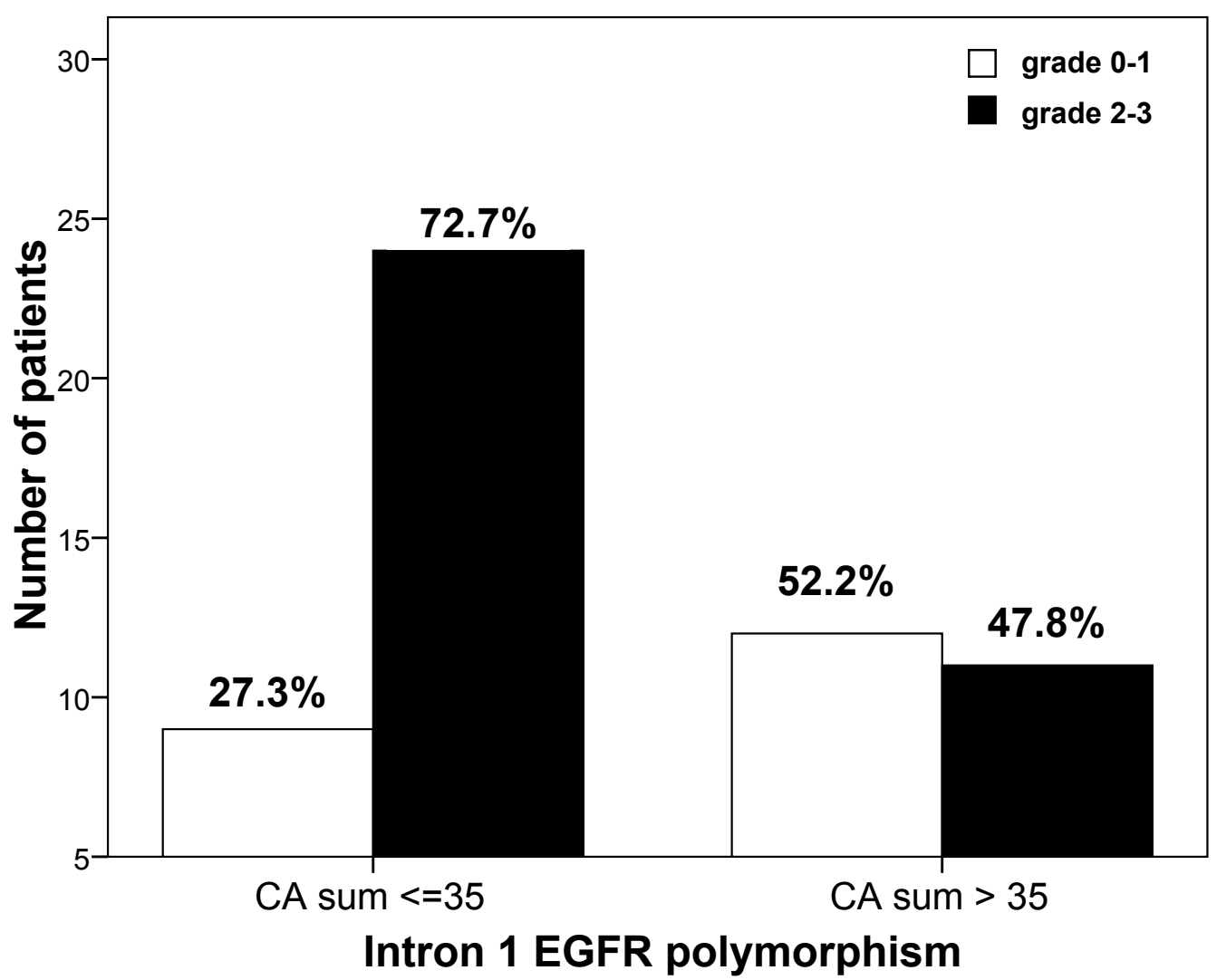

Figure 1 Relationship between cetuximab-related acneiform rash (maximum observed grade) and CA-repeats polymorphism in intron 1 of EGFR gene (CA sum $\leq 35$ vs CA sum $>35$ ). Chi-square test: $p=0.058$. OR relative to patients with CA sum $>35$ was 2.91 (95\% Cl 0.95 8.92).

and A870G CCND1 genotypes were related to TTP. Figure 3 shows a trend for a longer TTP in homozygous EGFR -191CC patients relative to other patients ( $\mathrm{p}=$ 0.050). CCND1 genotype had a significant impact on TTP, with a longer TTP in AA patients relative to GG patients and an intermediary TTP in heterozygous patients ( $p=0.037$, Figure 4). Kaplan-Meier analyses conducted in the sub-group of patients with KRas wt tumors reinforced the influence of both EGFR -191C > A (median 3.0 months in CC patients vs 2.6 months in $\mathrm{CA}+\mathrm{AA}$ patients $\mathrm{p}=0.030$ ) and CCND1 A870G (medians 7.9, 3.0 and 2.6 months in AA, AG and GG patients, respectively, $\mathrm{p}=0.024$ ) genotypes on TTP. A multivariate stepwise Cox analysis including both gene polymorphisms (considered as previously), on the whole population, only retained CCND1 polymorphism ( $\mathrm{p}=$ 0.057). This latter statistic became significant (CCND1 p $=0.035$, EGFR not retained in the analysis) in a multivariate stepwise analysis conducted on patients with KRas wt tumors (relative risk of progression in GG patients relative to AA patients was 5.59 , 95\% CI 1.3622.95; relative risk of progression in AG patients relative to AA patients was 2.32 , 95\% CI 0.66-8.17).
Median specific survival was 8.4 months. Specific survival was influenced by neither demographic nor tumor characteristics, including K-Ras mutation status. However, patients previously treated by bevacizumab had a significantly shorter survival (median 4.9 months, 13 patients, 11 cancer-related deaths) than those who did not receive bevacizumab (median 9.8 months, 44 patients, 33 cancer-related deaths, $\mathrm{p}=0.018$ ). Univariate analyses revealed a significant influence of FCGR3A F158V polymorphism on survival (FF vs FV vs VV, $\mathrm{p}<$ 0.001 ), with the $6 \mathrm{VV}$ patients having a markedly shorter survival (Figure 5). The influence of CCDN1 A870G polymorphism was at the limit of significance (AA vs AG vs GG, p = 0.050, Figure 6), with GG patients exhibiting the poorest survival. Other gene polymorphisms had no influence on specific survival. Univariate analyses conducted in the sub-group of patients with KRas wt tumors confirmed the impact of FCGR3A F158V polymorphism on survival (median 9.9, 9.0 and 2.9 months in FF, FV and VV patients, respectively, $\mathrm{p}=0.003$ ) and reinforced the significance of CCND1 A870G polymorphism (medians 9.9, 9.9 and 2.9 months in AA, AG and GG patients, respectively, $\mathrm{p}=0.024$ ). A multivariate 


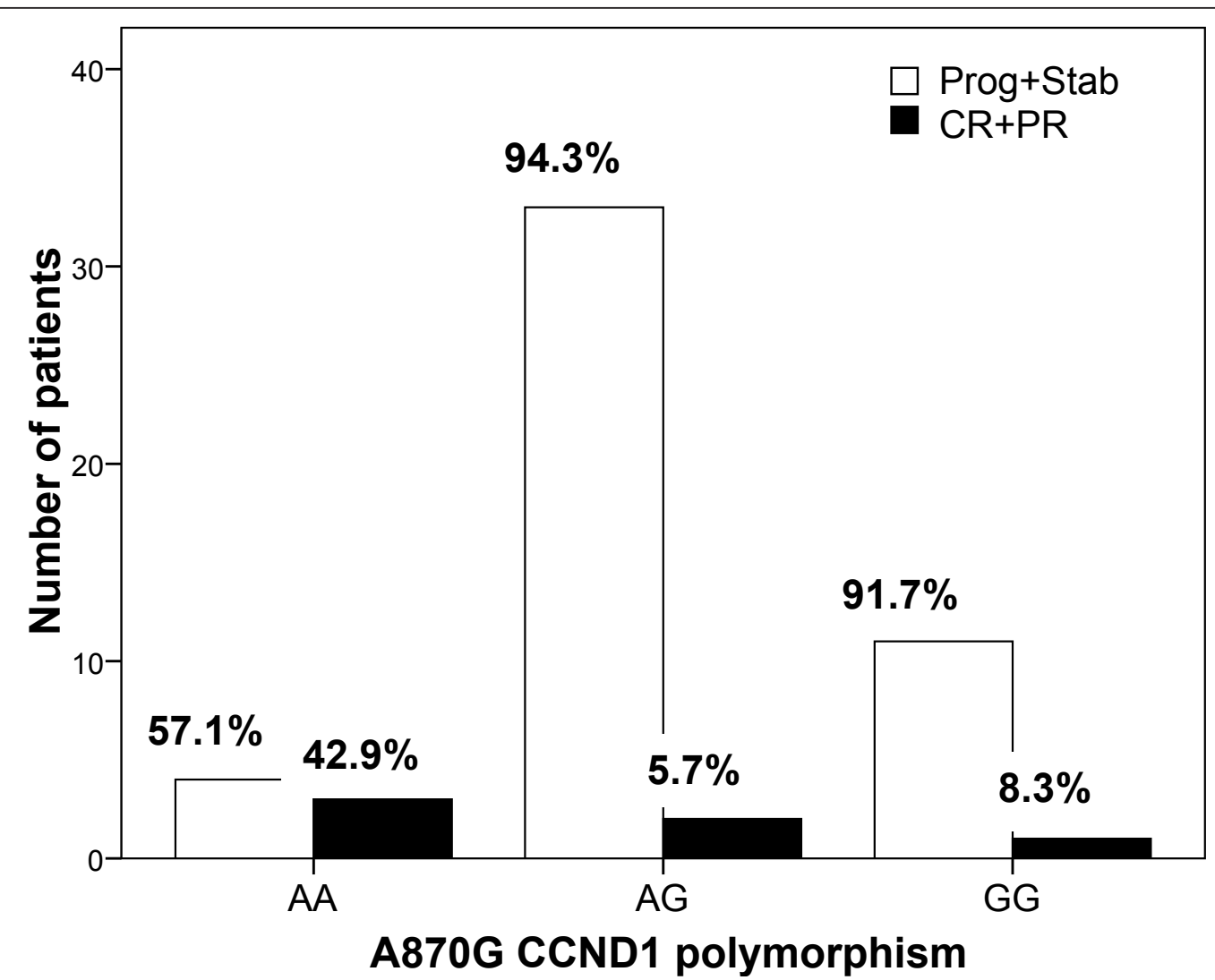

Figure 2 Relationship between best clinical response and CCND1 A870G gene polymorphism on the whole population. P value of chisquare test was 0.016 for $A A$ vs $A G$ vs $G G, 0.004$ for $A A$ vs $A G+G G$ and 0.73 for $A A+A G$ vs $G G$. Response rate was $6.4 \%$ in $A G+G G$ patients and $11.9 \%$ in $A A+A G$ patients.

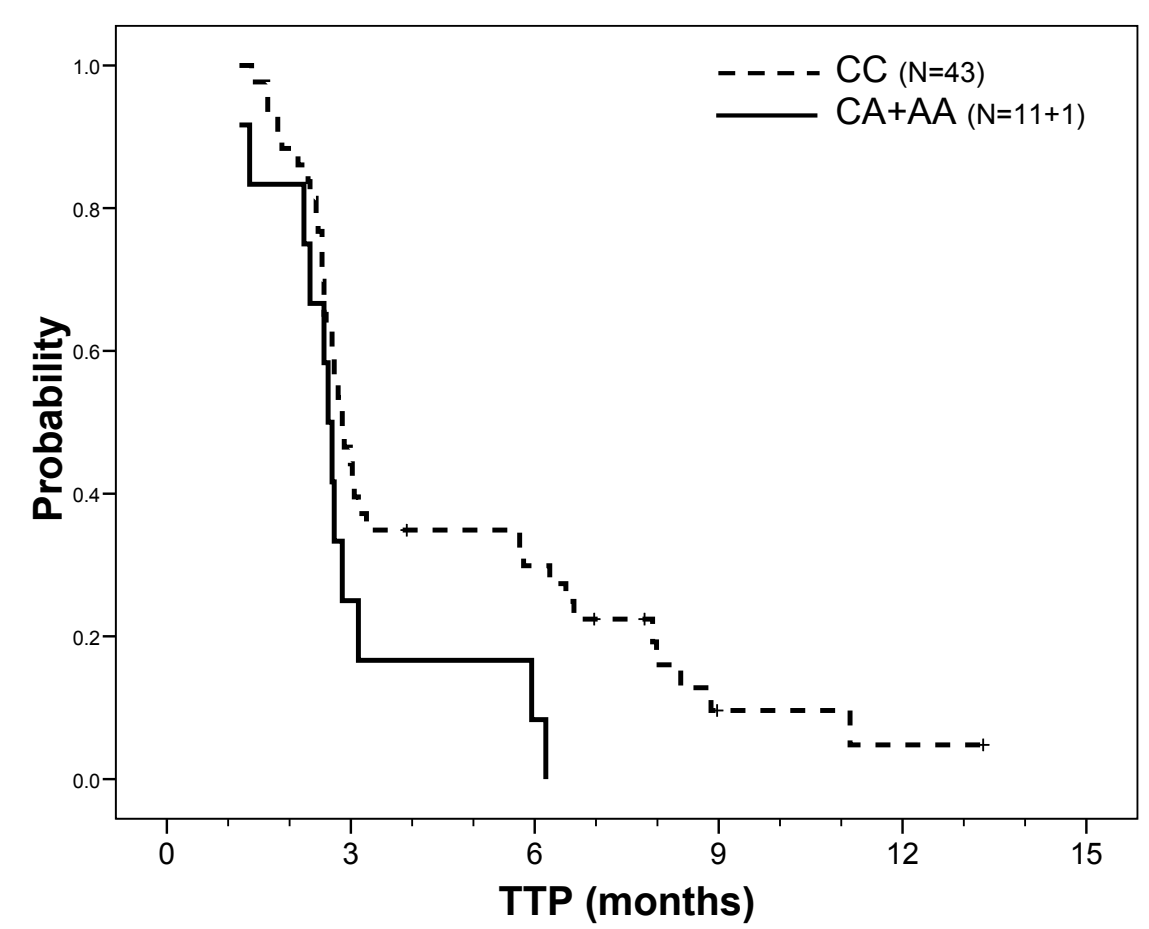

Figure 3 TTP probability according to EGFR -191C > A gene polymorphism on the whole population. Median TTP was 2.9 months in CC patients (43 patients, 38 events) vs 2.6 months in CA+AA patients (12 patients, 12 events); Log Rank test: $p=0.050$. 


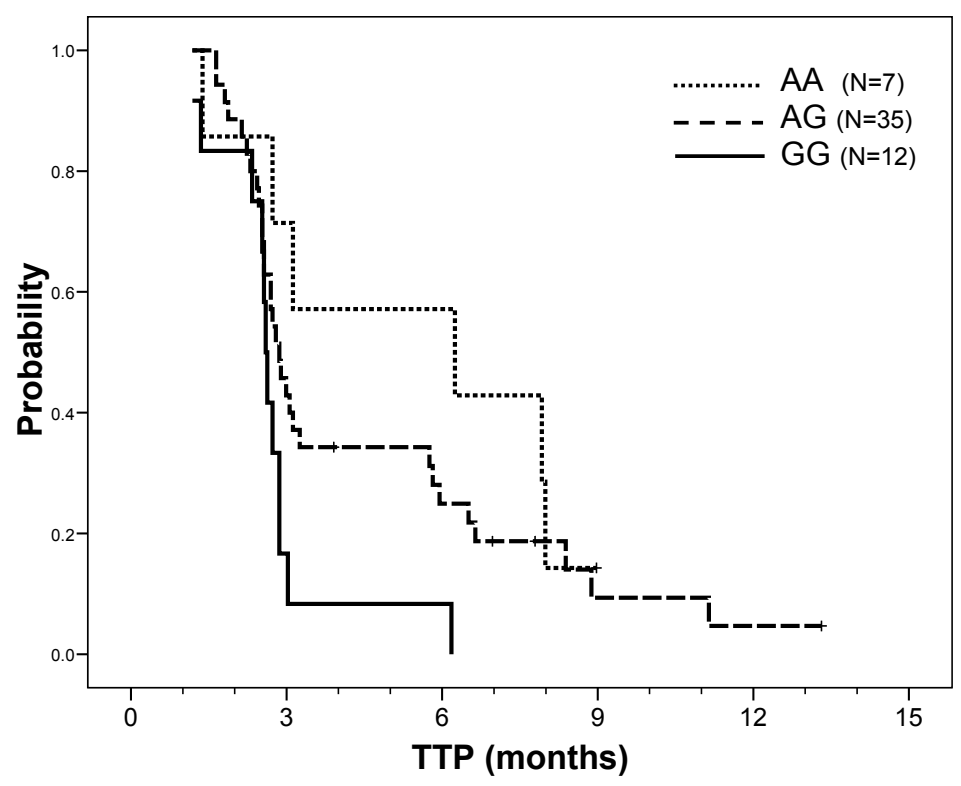

Figure 4 TTP probability according to CCND1 A870G gene polymorphism on the whole population. Median TTP was 6.3 months in AA patients (7 patients, 6 events) vs 2.9 months in AG patients (35 patients, 31 events) vs 2.6 months in GG patients (12 patients, 12 events); Log Rank test: $p=0.037$. Comparison of AA+AG patients (median TTP 2.9 months) vs GG patients gave a $p$ value at 0.016 .

stepwise analysis conducted on the entire population, including both gene polymorphisms considered as ternary variables along with bevacizumab pre-treatment (yes/no), revealed that CCND1 A870G ( $\mathrm{p}=0.044)$ and FCGR3A F158V ( $\mathrm{p}=0.006)$ polymorphisms were significant independent survival predictors $(\mathrm{p}=0.014$ for bevacizumab pre-treatment). Finally, this latter result was confirmed in a multivariate stepwise analysis conducted in the sub-group of patients with wt KRas tumors (p values were $0.021,0.036$ and 0.058 for CCND1, FCGR3A and bevacizumab pre-treatment, respectively).

\section{Discussion}

Cetuximab has shown efficacy in patients with metastatic colorectal cancer in several phase II trials leading, in 2004, to FDA approval for the treatment of irinotecanrefractory metastatic colorectal cancer. Several retrospective and prospective studies have clearly demonstrated that KRAS mutation confers resistance to these patients $[6-10,23,24]$ but the complete mechanism of cetuximab sensitivity remains only partially understood. The present study was conducted in patients receiving cetuximab before KRas-mutation testing was introduced as a requirement. As expected, no response rate was observed in mutated KRAS patients $v s 15.2 \%$ in wt tumors, even though the difference did not reach significance. We presently analyzed 8 gene polymorphisms involving 5 relevant candidate genes potentially related to the pharmacodynamics of cetuximab, namely EGFR, EGF, CCND1, FCGR2A and FCGR3A, on 58 CRC patients receiving cetuximab-based therapy. Statistical analyses were conducted in the whole set of patients, as well as in the sub-group of 34 patients with wt KRas tumors, so as to reflect the current cetuximab-treated population.

Numerous studies have reported a relationship between favorable outcome of cetuximab-treated patients and related skin toxicity $[2,3,25]$. Accordingly, present data show a higher response rate in patients developing grade 2-3 cutaneous toxicity as compared to patients with grade $0-1$ ( $14 \%$ vs $5 \%$, respectively), even though not significant. Present results also show a tendency for an association between intron 1 EGFR polymorphism and cetuximab-related skin toxicity: the incidence of grade 23 toxicity was 1.5 -fold greater in patients bearing short CA-repeats in intron 1 of EGFR gene (CA sum $\leq 35)$ as compared to others $(\mathrm{p}=0.058$, Figure 1$)$. This observation concords well with previous studies by Amador et al. [26] and Graziani et al. [27] reporting that patients developing cutaneous rash after anti-EGFR therapies presented shorter CA-repeats in intron 1 of EGFR gene as compared to patients who did not develop rash. Experimental studies have reported an inverse correlation between the number of CA-repeats in the intron 1 of the EGFR gene and EGFR gene transcription [28-30]. It can thus be hypothesized that elevated ubiquitous EGFR expression (including skin and tumor) renders the cells more susceptible to anti-EGFR effects.

In addition to the influence of intron 1 polymorphism on EGFR gene transcription, EGFR gene presents two functional polymorphisms in the promoter region: the 


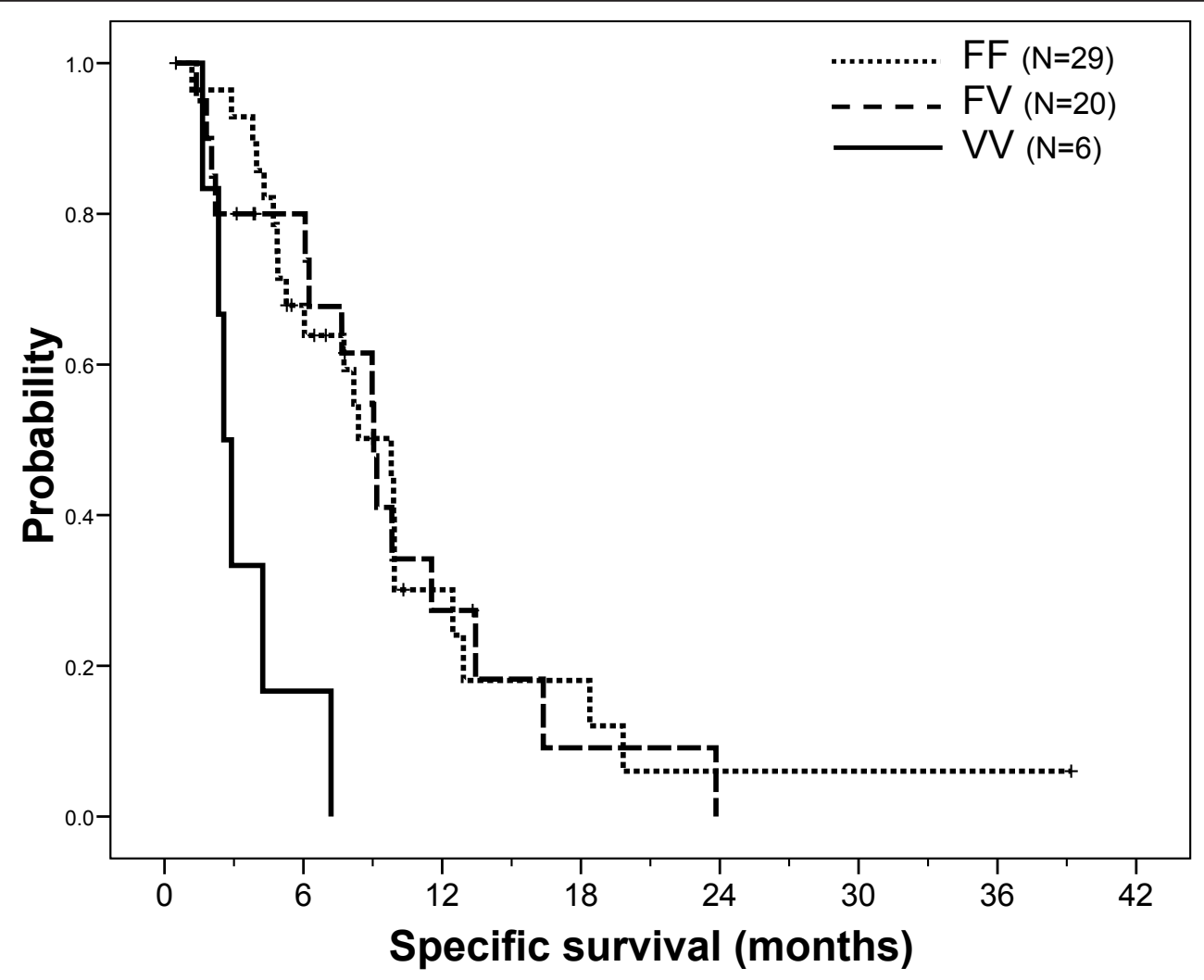

Figure 5 Specific survival (cancer-related death) probability according to FCGR3A F158V gene polymorphism on the whole population. Median survival was 9.8 months in FF patients (29 patients, 21 events) vs 9.0 months in FV patients (20 patients, 15 events) vs 2.6 months in W patients (6 patients, 6 events); Log Rank test: $p<0.001$. Comparison of FF patients vs others was not significant $(p=0.31)$ whereas comparison of $\mathrm{W}$ patients vs others gave a $\mathrm{p}$ value $<0.001$.

-216G/T polymorphism located in a Sp1 binding site [31,32], and the $-191 \mathrm{C} / \mathrm{A}$ polymorphism located $4 \mathrm{bp}$ upstream of a transcription initiation site [31]. These two SNPs may thus have an impact on EGFR gene regulation. Present data obtained on patients with wt KRas tumors show a significantly longer TTP in homozygous EGFR -191CC patients relative to other patients ( $\mathrm{p}=$ 0.030 , univariate analysis). However, this genotype was not retained in a multivariate analysis.

Cyclin D1 is a downstream effector of EGFR signaling that regulates cell cycle. The CCND1 A870G gene polymorphism affects the splice donor site at the exon 4/ intron 4 boundary, resulting in two different mRNA transcripts ( $\mathrm{a}$ and $\mathrm{b}$ ) [33]. Both the A allele and the $\mathrm{G}$ allele can encode these two transcripts. However, the A allele preferentially encodes transcript $b$, which results in a longer half-life cyclin D1 protein [33]. The impact of CCND1 A870G polymorphism on cancer progression has been studied in head and neck cancer patients, with conflicting results [34,35]. In our study, patients homozygous for the CCDN1 870AA genotype had a significantly greater response rate than AG or GG patients, both in the whole population and in patients with a wt
KRas tumor $(75.0 \%$ vs $7.1 \%$, respectively in wt KRas patients). In addition, patients with the CCND1 870AA genotype had a significantly longer median TTP than GG patients, with AG patients having an intermediary TTP, both in the whole population and in patients with a wt KRas tumor (median TTP were 7.9, 3.0 and 2.6 months, in AA, AG and GG wt KRas patients, respectively). Of note, in patients with wt KRas tumors, CCND1 polymorphism also influenced specific survival, with a significantly shorter survival in GG patients. The positive influences of CCND1 870A allele are thus consistent with one another, even though they do not concord with the sole published study having analyzed the impact of CCND1 A870G polymorphism on the outcome of advanced colorectal cancer patients receiving cetuximab therapy [36]. In this latter study, conducted on a limited sample of 39 patients, the $870 \mathrm{G}$ allele had a favorable impact on survival [36].

In addition to direct anti-EGFR effect, IgG1 mAbs such as cetuximab mediate anti-tumor effects by the ADCC mechanism. Fragment $\mathrm{C}$ of the mAb binds to the $\mathrm{Fc}$ receptors (FCR) carried by immune cells, thus triggering tumor cell lysis. Functional polymorphisms on 


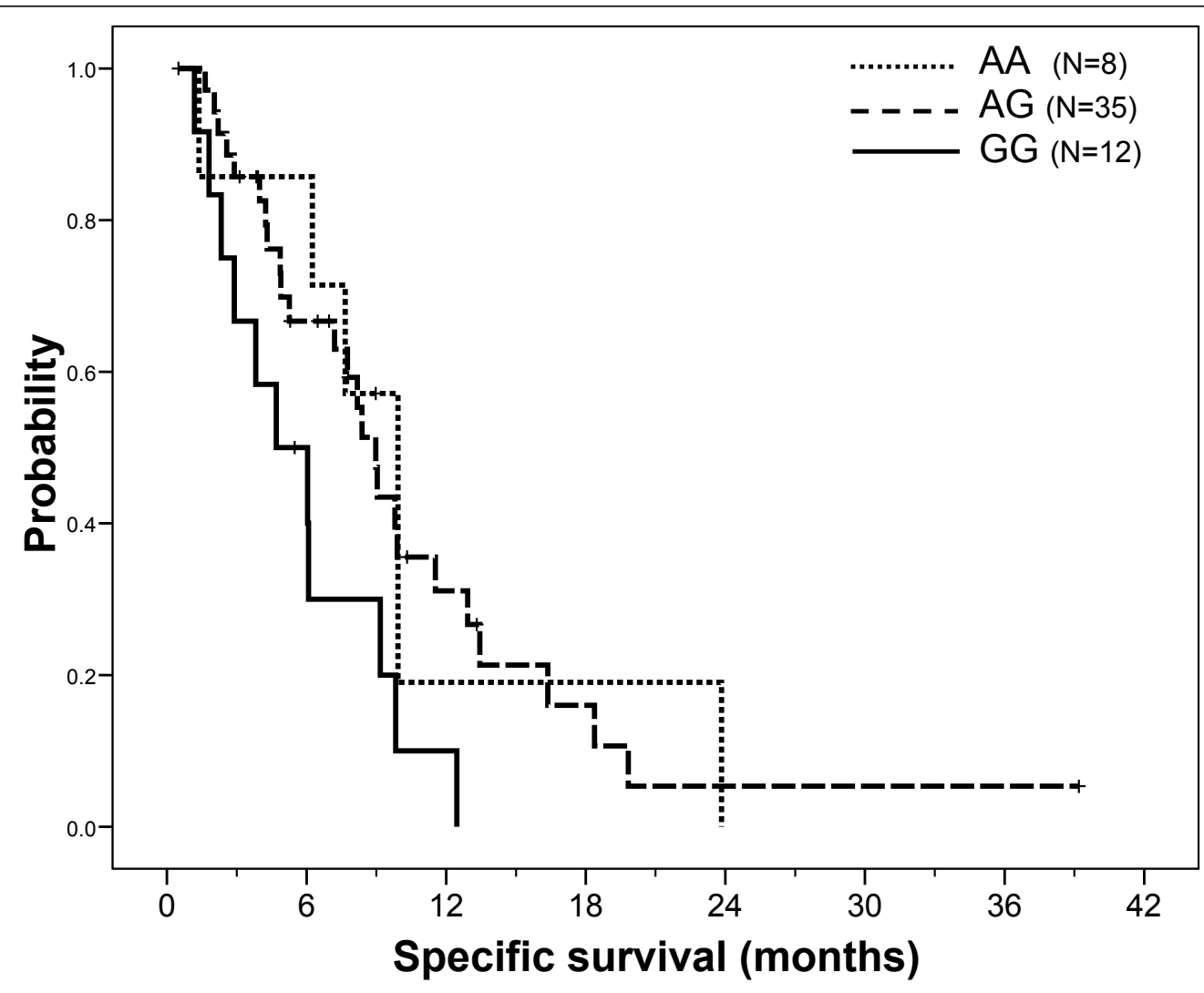

Figure 6 Specific survival (cancer-related death) probability according to CCND1 A870G gene polymorphism in the whole population Median survival was 9.9 months in AA patients (8 patients, 6 events) vs 9.0 months in AG patients (35 patients, 25 events) vs 4.7 months in GG patients (12 patients, 11 events); Log Rank test: $p=0.050$. Comparison of AA+AG patients (median survival 9.0 months) vs GG patients gave a $p$ value at 0.015 .

two FcR genes (FCGR2A, FCGR3A) affecting the affinity of FcR for fragment $C$ have been identified $[37,38]$. These polymorphisms may thus influence ADCC efficiency $[39,40]$. Even though some studies have reported significant associations between these polymorphisms and clinical efficacy of rituximab [41], trastuzumab [42] or cetuximab $[43,44]$, data conflict regarding which alleles are linked to favorable patient outcome. In the present study, we report a significant influence of FCGR3A F158V polymorphism on survival both in the whole population and in patients with a wt KRas tumor, with VV patients presenting a dramatically shorter survival. The favorable influence of the FCGR3A $158 \mathrm{~F}$ allele was also reported in a study by Zhang et al. [43] and a study by Pander et al. [45], but not in the study from Bibeau et al. [44]. These discrepancies related to the impact of FCGR3A 158F/V polymorphism on cetuximab efficacy are difficult to account for but could be due to the relatively limited sample size of these studies.

We observed that none of the 13 patients pre-treated with bevacizumab had a response to cetuximab and that this subgroup had a significantly decreased specific survival as compared with non-pretreated patients $(9.8$ months vs 4.9 months, $\mathrm{p}=0.018$ ). This difference remains statistically significant in a multivariate analysis adjusted for age, sex, PS status and KRas status (data not shown). This negative influence of bevacizumab pretreatment cannot be imputed to patient characteristics which were not significantly different between bevacizumab pretreated patients and non-pretreated patients, although it must be noted that $42 \%$ of bevacizumab pretreated patients carried KRAS mutated tumors vs $29 \%$ in non-pretreated patients $(\mathrm{p}=0.48)$. Importantly, a multivariate analysis including bevacizumab pretreatment revealed that CCND1 A870G and FCGR3A F158V polymorphisms both remained significant independent predictors of patient survival (whole population and KRas wt tumors).

The retrospective design of this study, conducted on a relatively small number of patients, may place intrinsic limitations on the present original data. However, results obtained in the sub-group of wt KRas patients, corresponding to the current cetuximab-treated population, clearly suggest that CCND1 A870G polymorphism may 
be used as an additional marker for predicting cetuximab efficacy, TTP and overall survival. Of note, FCGR3A F158V polymorphism and CCND1 A870G polymorphism were significant independent predictors of overall survival in patients with wt KRas tumors. Such promising observations deserve further confirmation in a prospective study conducted on a larger population of CRC patients receiving cetuximab-based therapy.

\section{Conflict of interests}

we declare that there is no conflict of interest that could be perceived as prejudicing the impartiality of the research reported.

\section{Acknowledgements}

We are grateful to Assistance Publique-Hôpitaux de Marseille. This research received no specific grant from any funding agency in the public, commercial or not-for-profit sector.

Final responsibility for the decision to submit for publication: $L$. Dahan

\section{Author details}

${ }^{1}$ Assistance Publique-Hôpitaux de Marseille, Hôpital Timone, Université de la Méditerranée, Marseille, France. 'Laboratoire d'oncopharmacologie, Centre Antoine Lacassagne, Nice, France. ${ }^{3}$ Assistance Publique-Hôpitaux de Marseille, Hôpital Nord, Université de la Méditerranée, Marseille, France.

\section{Authors' contributions}

Manuscript writing: LD, GM and MCEG

Review: LD, MCEG, GM

Investigators: LD, EN, JFS, MG

All authors read and approved the final manuscript

Received: 16 June 2011 Accepted: 25 November 2011

Published: 25 November 2011

\section{References}

1. Jemal A, Siegel R, Ward E, Murray T, Xu J, Smigal C, Thun MJ: Cancer statistics 2006. CA Cancer J Clin 2006, 56:106-30.

2. Saltz LB, Meropol NJ, Loehrer PJ Sr, Needle MN, Kopit J, Mayer RJ: Phase II trial of cetuximab in patients with refractory colorectal cancer that expresses the epidermal growth factor receptor. J Clin Oncol 2004, 22:1201-8

3. Cunningham D, Humblet $Y$, Siena $S$, Khayat $D$, Bleiberg $H$, Santoro A, Bets D, Mueser M, Harstrick A, Verslype C, Chau I, Van Cutsem E: Cetuximab monotherapy and cetuximab plus irinotecan in irinotecan-refractory metastatic colorectal cancer. N Engl J Med 2004, 351:337-45.

4. Tabernero J, Van Cutsem E, Díaz-Rubio E, Cervantes A, Humblet Y, André T, Van Laethem JL, Soulié P, Casado E, Verslype C, Valera JS, Tortora G, Ciardiello F, Kisker O, de Gramont A: Phase II trial of cetuximab in combination with fluorouracil, leucovorin, and oxaliplatin in the first-line treatment of metastatic colorectal cancer. J Clin Oncol 2007, 25:5225-32.

5. Baselga J: The EGFR as a target for anticancer therapy-focus on cetuximab. Eur J Cancer 2001, 37(Suppl 4):S16-22.

6. Karapetis CS, Khambata-Ford S, Jonker DJ, O'Callaghan CJ, Tu D, Tebbutt NC, Simes RJ, Chalchal H, Shapiro JD, Robitaille S, Price TJ, Shepherd L, Au HJ, Langer C, Moore MJ, Zalcberg JR: K-ras mutations and benefit from cetuximab in advanced colorectal cancer. $N$ Engl J Med 2008, 359:1757-65.

7. Di Fiore F, Blanchard F, Charbonnier F, Le Pessot F, Lamy A, Galais MP, Bastit L, Killian A, Sesboüé R, Tuech JJ, Queuniet AM, Paillot B, Sabourin JC, Michot $F$, Michel $P$, Frebourg T: Clinical relevance of KRAS mutation detection in metastatic colorectal cancer treated by Cetuximab plus chemotherapy. Br J Cancer 2007, 96:1166-9.
8. Benvenuti S, Sartore-Bianchi A, Di Nicolantonio F, Zanon C, Moroni M, Veronese S, Siena S, Bardelli A: Oncogenic activation of the RAS/RAF signaling pathway impairs the response of metastatic colorectal cancers to anti-epidermal growth factor receptor antibody therapies. Cancer Res 2007, 67:2643-8.

9. De Roock W, Piessevaux H, De Schutter J, Janssens M, De Hertogh G, Personeni N, Biesmans B, Van Laethem $J$, Peeters $M$, Humblet $Y$, Van Cutsem $E$, Tejpar S: KRAS wild-type state predicts survival and is associated to early radiological response in metastatic colorectal cancer treated with cetuximab. Ann Oncol 2008, 19:508-15.

10. Lièvre A, Bachet JB, Boige V, Cayre A, Le Corre D, Buc E, Ychou M, Bouché $\mathrm{O}$, Landi B, Louvet $C$, André T, Bibeau F, Diebold MD, Rougier P, Ducreux M, Tomasic G, Emile JF, Penault-Llorca F, Laurent-Puig P: KRAS mutations as an independent prognostic factor in patients with advanced colorectal cancer treated with cetuximab. J Clin Oncol 2008, 26(3):374-9.

11. Coate L, Cuffe S, Horgan A, Hung RJ, Christiani D, Liu G: Germline genetic variation, cancer outcome, and pharmacogenetics. J Clin Oncol 2010, 28:4029-37.

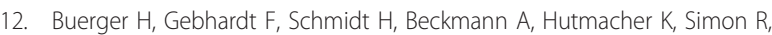
Lelle R, Boecker W, Brandt B: Length and loss of heterozygosity of an intron 1 polymorphic sequence of egfr is related to cytogenetic alterations and epithelial growth factor receptor expression. Cancer Res 2000, 60(4):854-7.

13. Moriai T, Kobrin MS, Hope C, Speck L, Korc M: A variant epidermal growth factor receptor exhibits altered type alpha transforming growth factor binding and transmembrane signaling. Proc Natl Acad Sci USA 1994, 91(21):10217-21.

14. Liu W, Innocenti F, Wu MH, Desai AA, Dolan ME, Cook EH Jr, Ratain MJ: A functional common polymorphism in a Sp1 recognition site of the epidermal growth factor receptor gene promoter. Cancer Res 2005, 65(1):46-53.

15. Shahbazi M, Pravica V, Nasreen N, Fakhoury H, Fryer AA, Strange RC, Hutchinson PE, Osborne JE, Lear JT, Smith AG, Hutchinson IV: Association between functional polymorphism in EGF gene and malignant melanoma. Lancet 2002, 359(9304):397-401.

16. Spindler KL, Nielsen JN, Ornskov D, Brandslund I, Jakobsen A: Epidermal growth factor (EGF) A61G polymorphism and EGF gene expression in normal colon tissue from patients with colorectal cancer. Acta Oncol 2007, 46(8):1113-7.

17. Le Marchand L, Seifried A, Lum-Jones A, Donlon T, Wilkens LR: Association of the cyclin D1 A870G polymorphism with advanced colorectal cancer. JAMA 2003, 290(21):2843-8.

18. Hong Y, Eu KW, Seow-Choen F, Fook-Chong S, Cheah PY: GG genotype of cyclin D1 G870A polymorphism is associated with increased risk and advanced colorectal cancer in patients in Singapore. Eur J Cancer 2005, 41(7):1037-44.

19. Weiner GJ: Monoclonal antibody mechanisms of action in cancer. Immunol Res 2007, 39(1-3):271-8, Review.

20. Kurai J, Chikumi H, Hashimoto K, Yamaguchi K, Yamasaki A, Sako T, Touge H, Makino H, Takata M, Miyata M, Nakamoto M, Burioka N, Shimizu E: Antibody-dependent cellular cytotoxicity mediated by cetuximab against lung cancer cell lines. Clin Cancer Res 2007, 13(5):1552-61.

21. van Sorge NM, van der Pol WL, van de Winkel JG: FcgammaR polymorphisms: Implications for function, disease susceptibility and immunotherapy. Tissue Antigens 2003, 61(3):189-202, Review.

22. Etienne-Grimaldi MC, Pereira S, Magné N, et al: Analysis of the dinucleotide repeat polymorphism in the epidermal growth factor receptor (EGFR) gene in head and neck cancer patients. Ann Oncol 2005, 16:934-941.

23. Van Cutsem E, Köhne CH, Hitre E, Zaluski J, Chang Chien CR, Makhson A, D'Haens G, Pintér T, Lim R, Bodoky G, Roh JK, Folprecht G, Ruff P, Stroh C, Tejpar S, Schlichting M, Nippgen J, Rougier P: Cetuximab and chemotherapy as initial treatment for metastatic colorectal cancer. $N$ Engl J Med 2009, 360(14):1408-17.

24. Bokemeyer C, Bondarenko I, Makhson A, Hartmann JT, Aparicio J, de Braud F, Donea S, Ludwig H, Schuch G, Stroh C, Loos AH, Zubel A, Koralewski P: Fluorouracil, leucovorin, and oxaliplatin with and without cetuximab in the first-line treatment of metastatic colorectal cancer. J Clin Oncol 2009, 27(5):663-71, Epub 2008 Dec 29 
25. Bianchini D, Jayanth A, Chua YJ, Cunningham D: Epidermal growth factor receptor inhibitor-related skin toxicity: mechanisms, treatment, and its potential role as a predictive marker. Clin Colorectal Cancer 2008, 7(1):33-43.

26. Amador ML, Oppenheimer D, Perea S, Maitra A, Cusatis G, lacobuzioDonahue C, Baker SD, Ashfaq R, Takimoto C, Forastiere A, Hidalgo M: An epidermal growth factor receptor intron 1 polymorphism mediates response to epidermal growth factor receptor inhibitors. Cancer Res 2004, 64(24):9139-43, Erratum in: Cancer Res. 2007, 67(16):7937.

27. Graziano F, Ruzzo A, Loupakis F, Canestrari E, Santini D, Catalano V, Bisonni R, Torresi U, Floriani I, Schiavon G, Andreoni F, Maltese P, Rulli E, Humar B, Falcone A, Giustini L, Tonini G, Fontana A, Masi G, Magnani M: Pharmacogenetic profiling for cetuximab plus irinotecan therapy in patients with refractory advanced colorectal cancer. J Clin Oncol 2008, 26(9):1427-34.

28. Buerger H, Gebhardt F, Schmidt H, Beckmann A, Hutmacher K, Simon R, Lelle R, Boecker W, Brandt B: Length and loss of heterozygosity of an intron 1 polymorphic sequence of egfr is related to cytogenetic alterations and epithelial growth factor receptor expression. Cancer Res 2000, 60(4):854-7.

29. Buerger H, Packeisen J, Boecker A, Tidow N, Kersting C, Bielawski K, Isola J, Yatabe $Y$, Nakachi K, Boecker W, Brandt B: Allelic length of a CA dinucleotide repeat in the egfr gene correlates with the frequency of amplifications of this sequence-first results of an inter-ethnic breast cancer study. J Pathol 2004, 203(1):545-50.

30. Gebhardt F, Zänker KS, Brandt B: Modulation of epidermal growth factor receptor gene transcription by a polymorphic dinucleotide repeat in intron 1. J Biol Chem 1999, 274(19):13176-80.

31. Johnson AC, Ishii S, Jinno Y, Pastan I, Merlino GT: Epidermal growth factor receptor gene promoter. Deletion analysis and identification of nuclear protein binding sites. J Biol Chem 1988, 263(12):5693-9.

32. Kageyama R, Merlino GT, Pastan I: Epidermal growth factor (EGF) receptor gene transcription. Requirement for Sp1 and an EGF receptor-specific factor. J Biol Chem 1988, 263(13):6329-36.

33. Betticher DC, Thatcher N, Altermatt HJ, Hoban P, Ryder WD, Heighway J: Alternate splicing produces a novel cyclin D1 transcript. Oncogene 1995, 11(5):1005-11.

34. Izzo JG, Papadimitrakopoulou VA, Liu DD, den Hollander PL, Babenko IM, Keck J, El-Naggar AK, Shin DM, Lee JJ, Hong WK, Hittelman WN: Cyclin D1 genotype, response to biochemoprevention, and progression rate to upper aerodigestive tract cancer. J Natl Cancer Inst 2003, 95(3):198-205.

35. Matthias C, Branigan K, Jahnke V, Leder K, Haas J, Heighway J, Jones PW, Strange RC, Fryer AA, Hoban PR: Polymorphism within the cyclin D1 gene is associated with prognosis in patients with squamous cell carcinoma of the head and neck. Clin Cancer Res 1998, 4(10):2411-8, Erratum in: Clin Cancer Res 1999, 5(1):222.

36. Zhang W, Gordon M, Press OA, Rhodes K, Vallböhmer D, Yang DY, Park D, Fazzone W, Schultheis A, Sherrod AE, labal S, Groshen S, Lenz HJ: Cyclin D1 and epidermal growth factor polymorphisms associated with survival in patients with advanced colorectal cancer treated with Cetuximab. Pharmacogenet Genomics 2006, 16(7):475-83.

37. Shields RL, Namenuk AK, Hong K, Meng YG, Rae J, Briggs J, Xie D, Lai J, Stadlen A, Li B, Fox JA, Presta LG: High resolution mapping of the binding site on human IgG1 for Fc gamma Rl, Fc gamma RIl, Fc gamma RIII, and FcRn and design of IgG1 variants with improved binding to the Fc gamma R. J Biol Chem 2001, 276(9):6591-604, Epub 2000 Nov 28.

38. Wu J, Edberg JC, Redecha PB, Bansal V, Guyre PM, Coleman K, Salmon JE, Kimberly RP: A novel polymorphism of FcgammaRIlla (CD16) alters receptor function and predisposes to autoimmune disease. J Clin Invest 1997, 100(5):1059-70.

39. Niwa R, Hatanaka S, Shoji-Hosaka E, Sakurada M, Kobayashi Y, Uehara A, Yokoi H, Nakamura K, Shitara K: Enhancement of the antibody-dependent cellular cytotoxicity of low-fucose lgG1 Is independent of FcgammaRIlla functional polymorphism. Clin Cancer Res 2004, 10(18 Pt 1):6248-55.

40. van Royen-Kerkhof A, Sanders EA, Wijngaarden S, van Roon JA, VoorhorstOgink M, Walraven V, Gerritsen A, van Dijk MA, Kuis W, Rijkers GT, Keler T, Leusen $J H$, van de Winkel JG: Flow cytometric determination of FcgammaRlla (CD32) polymorphism. J Immunol Methods 2004, 294(12):135-44, Epub 2004 Oct 6.

41. Cartron G, Dacheux L, Salles G, Solal-Celigny P, Bardos P, Colombat P, Watier $\mathrm{H}$ : Therapeutic activity of humanized anti-CD20 monoclonal antibody and polymorphism in IgG Fc receptor FcgammaRIlla gene. Blood 2002, 99(3):754-8.

42. Musolino A, Naldi N, Bortesi B, et al: Immunoglobulin G fragment C receptor polymorphisms and clinical efficacy of trastuzumab-based therapy in patients with HER-2-neu-positive metastatic breast cancer. J Clin Oncol 2008, 26(11):1789-96.

43. Zhang W, Gordon M, Schultheis AM, Yang DY, Nagashima F, Azuma M, Chang HM, Borucka E, Lurje G, Sherrod AE, labal S, Groshen S, Lenz HJ: FCGR2A and FCGR3A polymorphisms associated with clinical outcome of epidermal growth factor receptor expressing metastatic colorectal cancer patients treated with single-agent cetuximab. J Clin Oncol 2007, 25(24):3712-8

44. Bibeau F, Lopez-Crapez E, Di Fiore F, Thezenas S, Ychou M, Blanchard F, Lamy A, Penault-Llorca F, Frébourg T, Michel P, Sabourin JC, BoissièreMichot F: Impact of Fc\{gamma\}RIlla-Fc\{gamma\}RIlla polymorphisms and KRAS mutations on the clinical outcome of patients with metastatic colorectal cancer treated with cetuximab plus irinotecan. J Clin Oncol 2009, 27(7):1122-9, Epub 2009 Jan 21.

45. Pander J, Gelderblom H, Antonini NF, Tol J, van Krieken JHJM, van der Straaten T, Punt CJA, Guchelaar HJ: Correlation of FCGR3A and EGFR germline polymorphisms with the efficacy of cetuximab in KRAS wildtype metastatic colorectal cancer. Eur J Cancer 2010, 46:1829-34.

Pre-publication history

The pre-publication history for this paper can be accessed here: http://www.biomedcentral.com/1471-2407/11/496/prepub

doi:10.1186/1471-2407-11-496

Cite this article as: Dahan et al:: Pharmacogenetic profiling and cetuximab outcome in patients with advanced colorectal cancer. BMC Cancer 2011 11:496.

\section{Submit your next manuscript to BioMed Central and take full advantage of:}

- Convenient online submission

- Thorough peer review

- No space constraints or color figure charges

- Immediate publication on acceptance

- Inclusion in PubMed, CAS, Scopus and Google Scholar

- Research which is freely available for redistribution

Submit your manuscript at www.biomedcentral.com/submit
Biomed Central 